\title{
Class II malocclusion treatment using Jasper Jumper appliance associated to intermaxillary elastics: A case report
}

\author{
Francyle Simões Herrera-Sanches', José Fernando Castanha Henriques², Guilherme Janson², Leniana Santos Neves³,
} Karina Jerônimo Rodrigues Santiago de Lima ${ }^{4}$ Rafael Pinelli Henriques ${ }^{5}$, Lucelma Vilela Pieri ${ }^{5}$

Introduction: Skeletal, dental and profile discrepancies can be amended by using functional orthodontic appliances. Objective: This study is a report of the treatment of a patient, 11 years and 4 months old, with Class II, division 1, malocclusion, convex profile, protrusion of upper incisors, pronounced overjet and overbite, and mild crowding. Methods: The patient was treated with a Jasper Jumper associated to fixed appliances for 6 months and Class II intermaxillary elastics (3/16in) during the last 4 months. After debonding, a Hawley retainer was used during daytime and a modified Bionator for night use during one year. In the lower dental arch a bonded lingual retainer was used. This treatment combination improved the profile, as well as the overjet, overbite and molar relation. Results: There was clockwise mandibular rotation and increase of lower anterior facial height. The lower incisors were protruded and extruded and the lower molars were extruded. The centric occlusal relation was checked and it was coincident to the maximum usual intercuspation. Conclusion: It was demonstrated that the Jasper Jumper is an efficient alternative to Class II malocclusion treatment, providing improvement in the facial profile, although the changes are more dentoalveolar than skeletal.

Keywords: Angle Class II malocclusion. Corrective orthodontics. Functional orthodontic appliances.

Introdução: discrepâncias esqueléticas, dentárias e de perfil podem ser melhoradas com a utilização de aparelhos ortopédicos funcionais. Objetivo: esse artigo tem o objetivo de relatar o tratamento de um paciente de 11 anos e 4 meses de idade com má oclusão de Classe II divisão 1, 1/2 cúspide bilateral, alteração de perfil, protrusão dos incisivos superiores, overjet e overbite acentuados e apinhamento suave. Métodos: o paciente foi tratado por meio do Jasper Jumper associado ao aparelho fixo por 6 meses e elásticos intermaxilares de Classe II (3/16”) nos últimos 4 meses. Após a remoção do aparelho fixo, foram utilizadas as contenções, a placa de Hawley para uso diurno e o Bionator modificado para uso noturno, por um ano. No arcada inferior, foi utilizada contenção $3 \times 3$ fixa colada de canino a canino. Essa combinação de tratamento melhorou o perfil, bem como os trespasses horizontal e vertical, além da relação molar. Resultados: houve rotação mandibular no sentido horário e aumento da altura facial anteroinferior. Os incisivos inferiores foram protruídos e extruídos, e os molares inferiores sofreram extrusão. A relação cêntrica oclusal foi checada e era coincidente com a máxima intercuspidação habitual. Conclusão: comprovou-se que o Jasper Jumper é uma alternativa eficiente para o tratamento da Classe II, proporcionando melhoras no perfil facial, embora as alterações sejam mais dentoalveolares do que esqueléticas.

Palavras-chave: Má oclusão Classe II de Angle. Ortodontia corretiva. Aparelhos ortodônticos funcionais.

${ }^{1} \mathrm{MSc}$ in Orthodontics, FOB-USP.

${ }^{2}$ Full Professor, Department of Orthodontics, FOB-USP.

${ }^{3}$ Professor of the Specialization Course in Orthodontics, Federal University of

Vale do Jequitinhonha and Mucuri.

${ }^{4}$ Adjunct Professor, Federal University of Paraíba.

${ }^{5} \mathrm{PhD}$ in Orthodontics, FOB-USP.

Submitted: July 6, 2009 - Revised and accepted: November 30, 2010

» Patients displayed in this article previously approved the use of their facial and intraoral photographs.
How to cite this article: Herrera-Sanches FS, Henriques JFC, Janson G, Neves LS, Lima KJRS, Henriques RP, Pieri LV. Class II malocclusion treatment using Jasper Jumper appliance associated to intermaxillary elastics: A case report. Dental Press J Orthod. 2013 Mar-Apr;18(2):22-9.

» The authors report no commercial, proprietary or financial interest in the products or companies described in this article.

Contact address: Francyle Simões Herrera-Sanches Rua Mário Ranieri, 4-45, lote E-9 - Resid. Jardins do Sul - Bauru/SP, Brazil CEP: 17.053-902 - E-mail: francyle@gmail.com 


\section{INTRODUCTION}

The Class II, division 1, malocclusion, is well studied in Orthodontics, being responsible for 12 to $49 \%$ of the occlusal problems. ${ }^{5,7}$ The most common feature in this type of malocclusion is the mandibular retrusion. ${ }^{9}$ Therefore, the redirection of the mandibular growth is the main objective of the Class II treatment. Another treatment goal is the reduction of overjet and overbite and the achievement of molar Class I relationship in a one phase nonextraction treatment.

Besides the skeletal discrepancy, the facial profile can be improved with the use of functional appliances. Several protocols and appliances can be used for this type of treatment, depending on age, sagittal discrepancy and patient cooperation. ${ }^{11}$ The beginning of a Class II combined treatment uses mechanics with the purpose of increasing the efficiency of the conventional treatment for this malocclusion, besides it requires less patient cooperation. This technique combines orthodontic and orthopedic mechanics in one phase treatment with fixed appliances. ${ }^{2}$

The Jasper Jumper is a fixed functional appliance considered as an effective option for Class II, division I treatment. ${ }^{1,10,14}$ It is made of a flexible intraoral power module, which is comparable to the Herbst appliance, with the advantage of flexibility, and is considered excellent due to great toleration by patients. This appliance was developed to perform light and continuous forces for Class II correction, simulating the effects of the headgear and the activator appliances. ${ }^{3,6}$

On its effects, this appliance corrects the malocclusion by dentoalveolar changes, being useful in cases where growth has ended or is going to end. ${ }^{12}$ Another indication is for those patients that refuse orthognathic surgery. This appliance eliminates the need for patient cooperation, ${ }^{11}$ but when it faces constant breakage and repair, they can transfer the collaboration to the professional.

Although a number of studies show the clinical efficiency of this appliance on the correction of the Class II, division 1 malocclusion, there are few clinical cases published in the literature.

\section{HISTORY AND DIAGNOSIS}

An 11,36 year old boy, with Class II, division 1, malocclusion, in the permanent dentition, with protruded upper incisors, mild crowding of upper and lower incisors, $7 \mathrm{~mm}$ overjet, 5,2 $\mathrm{mm}$ overbite, convex profile and poor oral hygiene (Figs 1 and 2) sought treatment at the orthodontic clinic of FOB-USP.

\section{TREATMENT OBJECTIVES}

1. Correct the molar Class II relationship to a Class I with a mutually protected and maximum intercuspated occlusion.

2. Retraction of upper incisors to correct the overjet and achieve an acceptable interincisal angle.

3. Improve the facial profile by correcting the overjet.

4. Achieve a nice smile providing vertical dimension and reducing the overjet.

5. Ideally align the completely erupted permanent teeth and correct the upper midline discrepancy.

\section{TREATMENT ALTERNATIVES}

Three alternatives were offered to the patient and his parents: (1) The use of a headgear, (2) Jasper Jumper appliance associated to fixed appliances, (3) extraction of two upper premolars. They chose the second option, which required less patient cooperation.

\section{TREATMENT PROGRESS}

The patient was instructed on oral hygiene before appliance placement. Brackets of the straight arch technique (Roth system, slot 0.022-in. Morelli ${ }^{\circledR}$ ) were bonded, as well as bands with triple tubes with a palatal bar cemented to the upper first permanent molars to increase stability and prevent side effects. The leveling and alignment lasted five months (Fig 3) and continuous archwires were used with the following sequence: 0.016 -in NiTi; 0.018-in SS, 0.020-in SS and $0.019 \times 0.025$-in SS. The mandibular arch was tied back to the first or second permanent molars. On the upper arch, the Jumper was inserted in the round tube of the first molars with a ball pin. On the lower arch, the Jumper was inserted in the rectangular archwire with a stop and acrylic spheres over the distal side of the canine bracket. The Jasper Jumpers were selected according the manufacturer's instruction. A rectangular $0.019 \times 0.025$-in SS archwire was used in both arches during the use of the Jasper Jumper (Fig 3). 

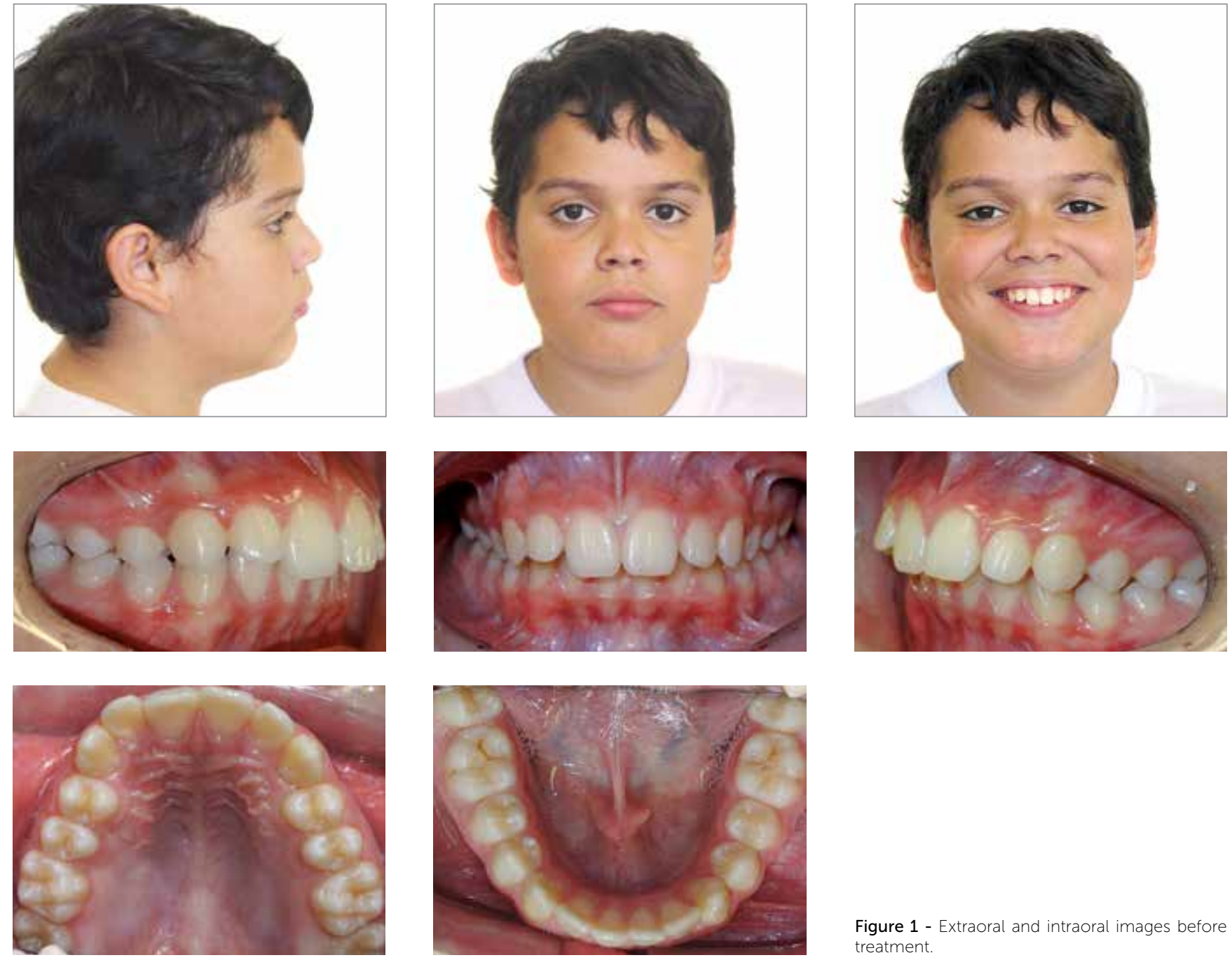

Figure 1 - Extraoral and intraoral images before treatment.
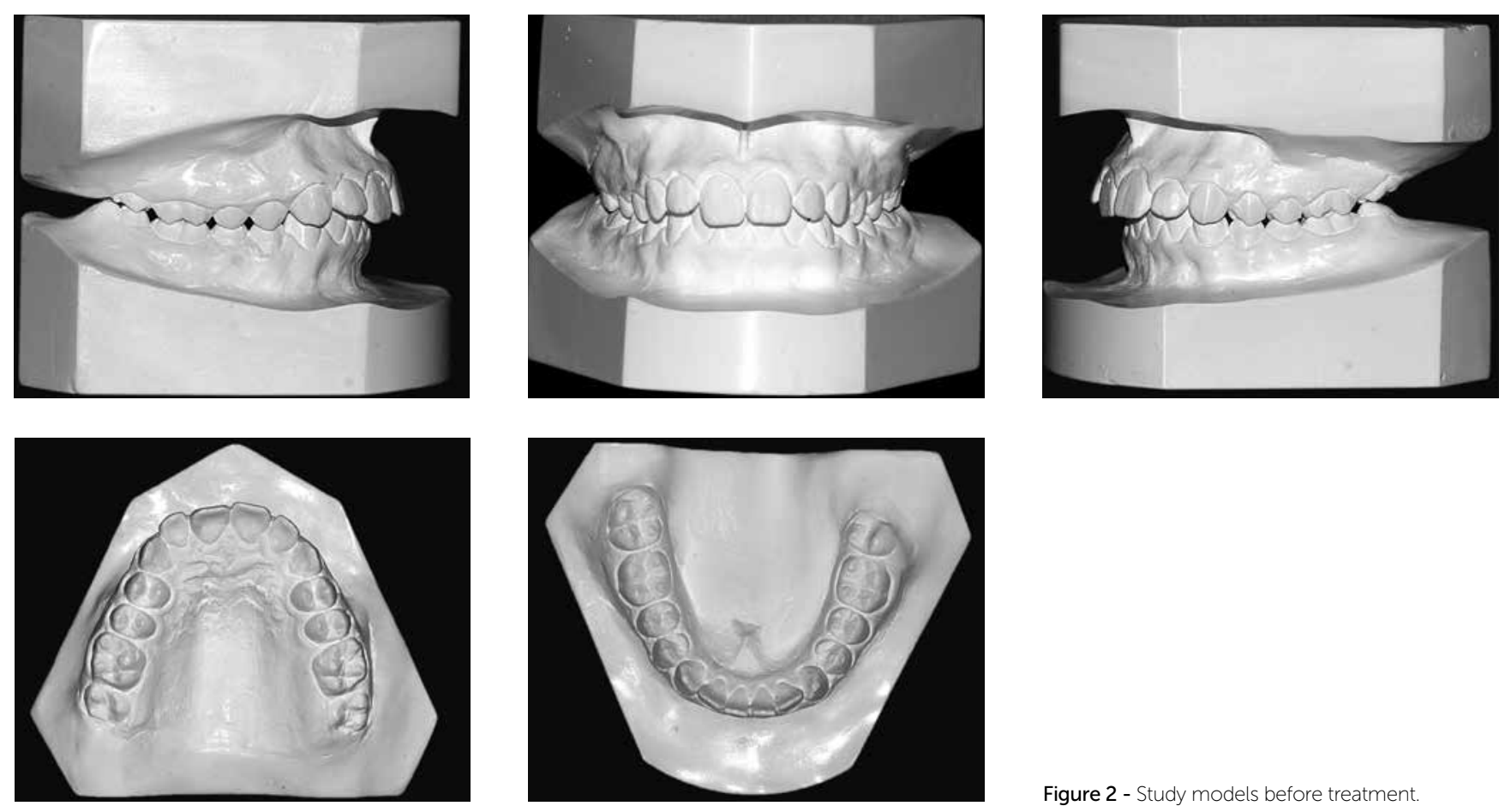

Figure 2 - Study models before treatment 
The patient was seen every four weeks and the Jasper Jumper activated every eight weeks. The Jasper Jumper was removed when the molar and canines reached a Class I relationship or overcorrection (Figs 4 and 5). The treatment period with the Jasper Jumper was six months. After Jumpers removal, the teeth were retained with 3/16-in Class II elastics for a mean period of four months.

The centric occlusal relationship was checked and it was coincident to the centric occlusion. After debonding, a Hawley retainer was used during the day on the upper arch and a modified Bionator at night during one year. Also, a $3 \times 3$ lower fixed retainer was used until the end of craniofacial growth (Figs 5, 6 and 7)

\section{RESULTS}

The treatment with the Jasper Jumper improved the patient's profile as well as the overjet, overbite and molar relationship. However, it caused clockwise mandibular rotation and increase of lower anterior facial height. The lower incisors were protruded and extruded and the lower molars were extruded.

\section{DISCUSSION}

A favorable improvement of the facial profile (Table 1), shows that the Jasper Jumper had a positive effect. As the upper incisors retruded, the upper lip retracted and ceased the interference of the lower lip with the upper incisors. Apart from this, the flaring of the lower incisors gave support to the lower lip. The lip length reduced favorably, due to the retrusion of the upper incisors. Previous studies showed similar soft tissue changes. ${ }^{8,13}$

The mechanism of the Jasper Jumper appliance consists in forward orthodontic force on the mandible and a backward mechanical loading on the maxilla. The effect of the latter resulted in the reduction of the effective length of the maxilla (Co-A). This was the only skeletal change caused by the appliance. This finding agrees with the results of other investigators that reported that the Jasper Jumper had a headgear effect on the maxilla. These effects were expected according to previous studies, ${ }^{4}$ but as shown in several studies and in this clinical case, the orthodontic effects are more expressed than the orthopedic. At the same time, the Jumper exerts an intrusive force on the anterior portion of the lower dentition and on the posterior portion
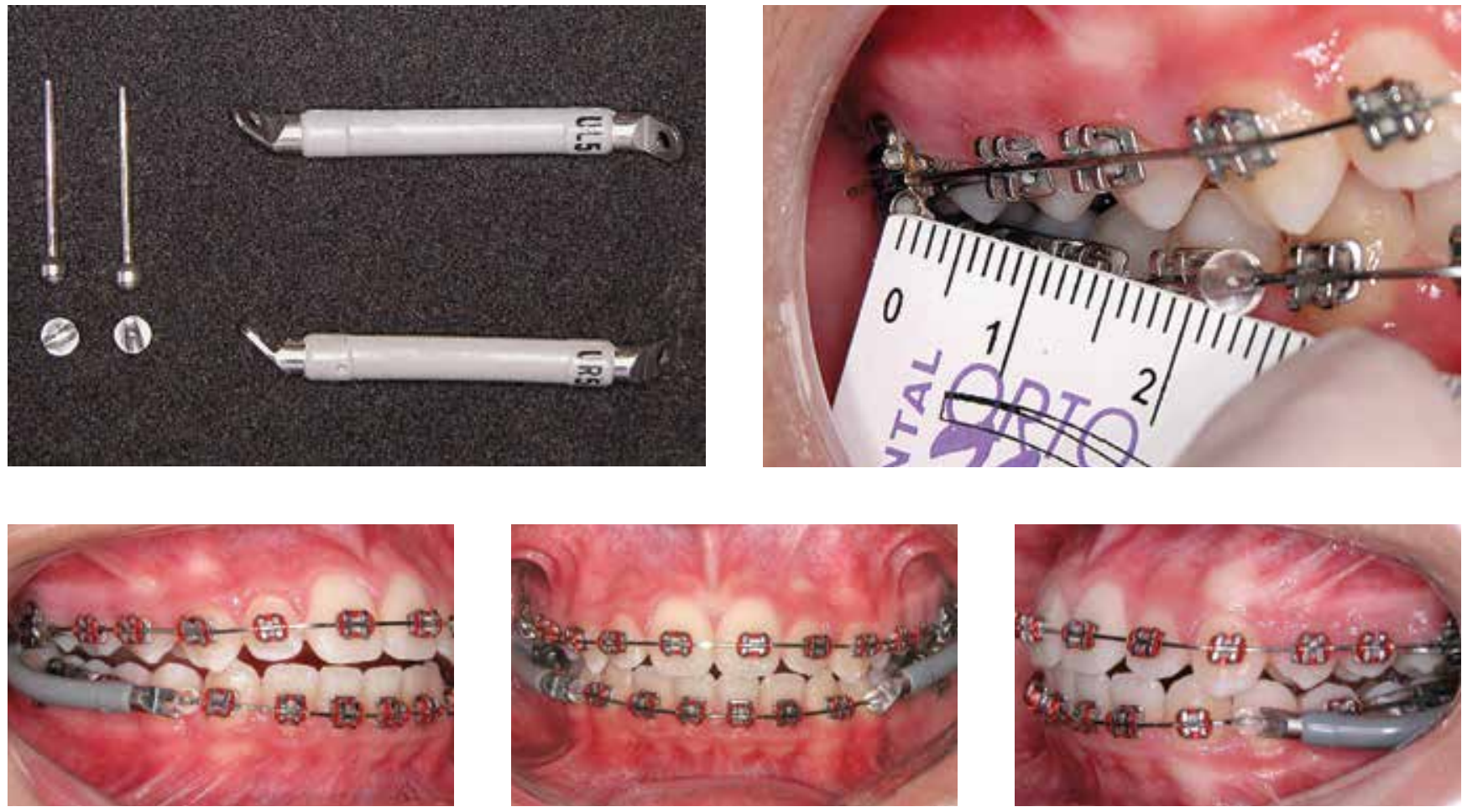

Figure 3 - After alignment and leveling with fixed appliances - Installation of Jasper Jumper and mandibular advancement. 

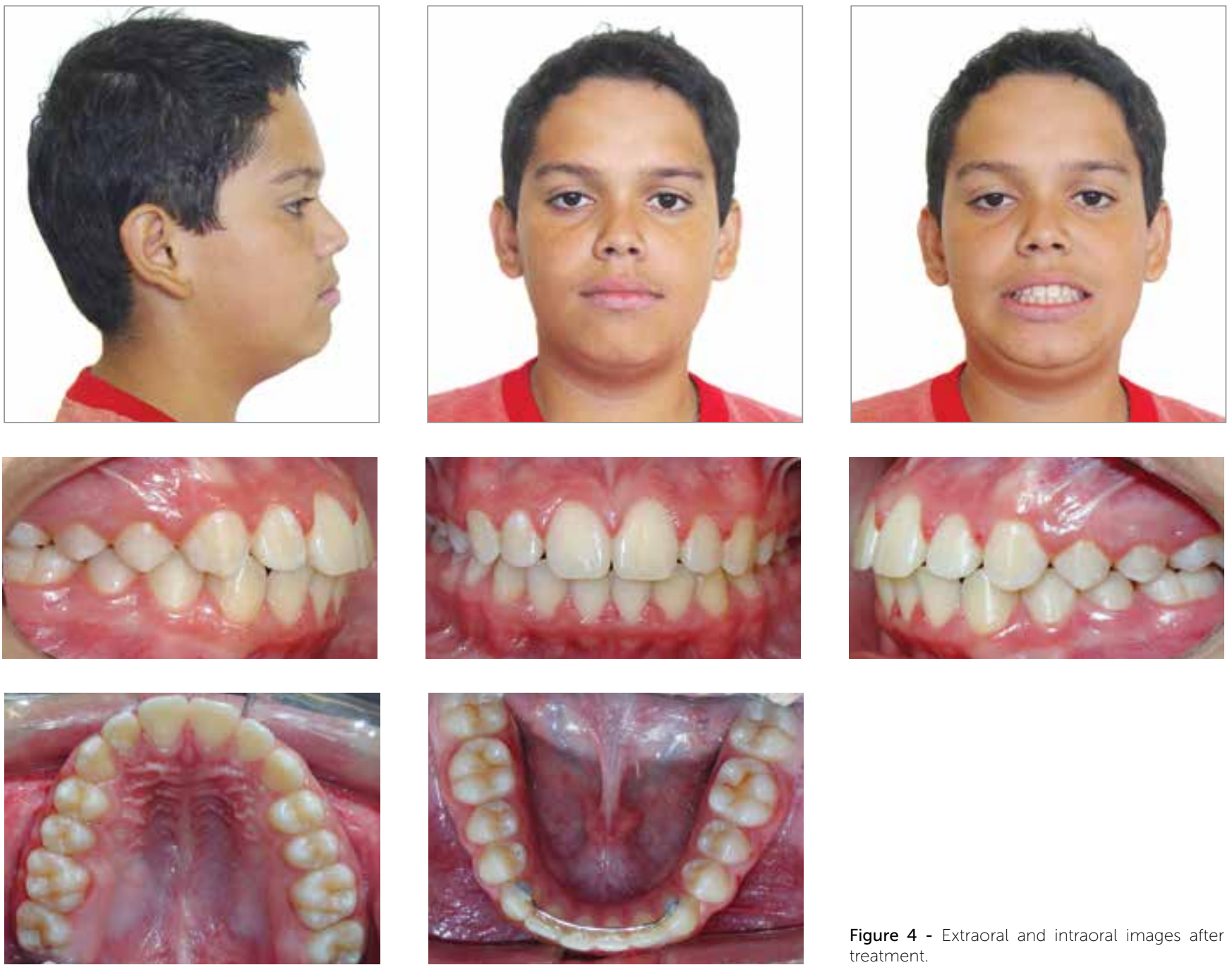

Figure 4 - Extraoral and intraoral images after treatment.
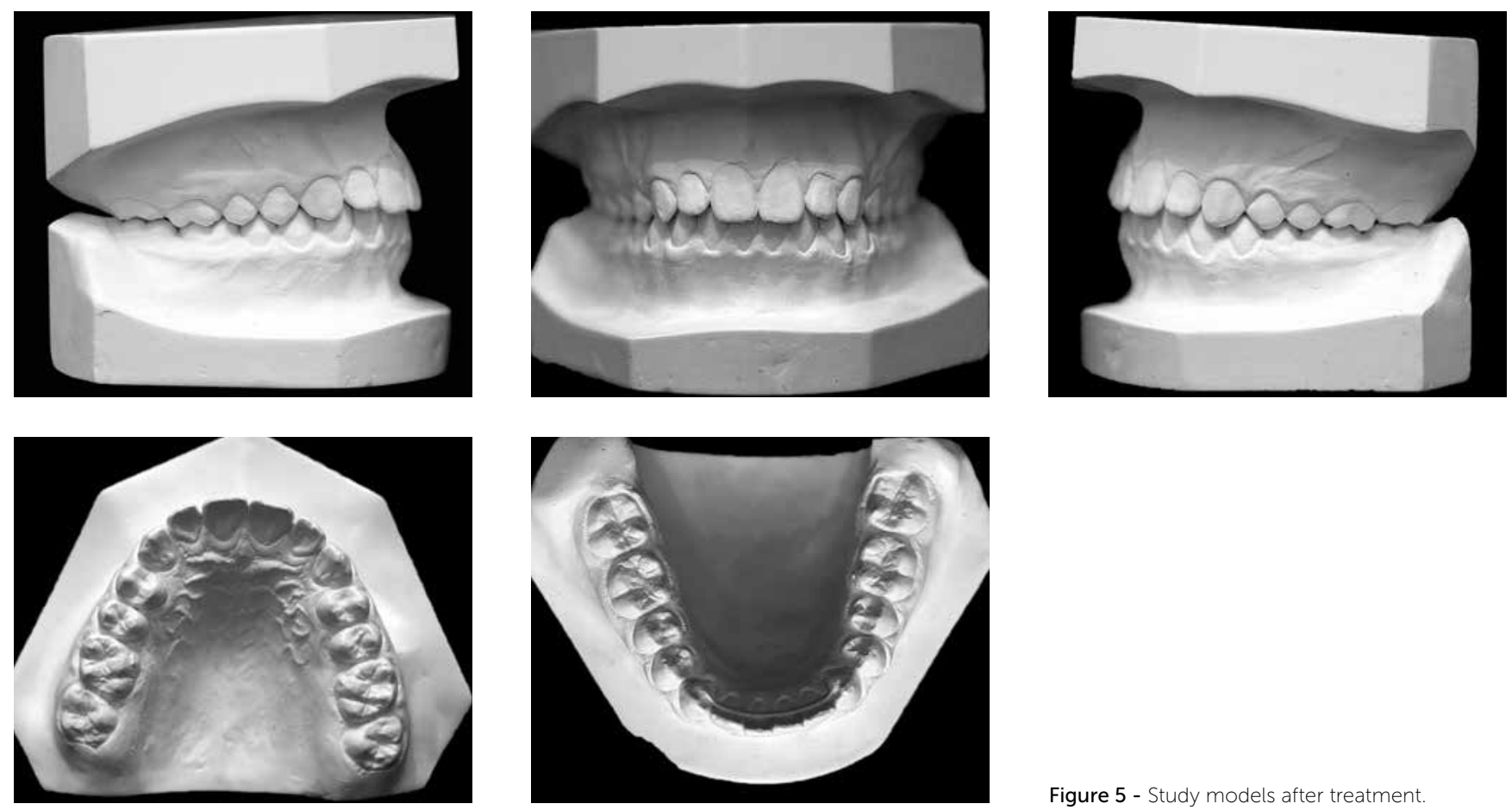

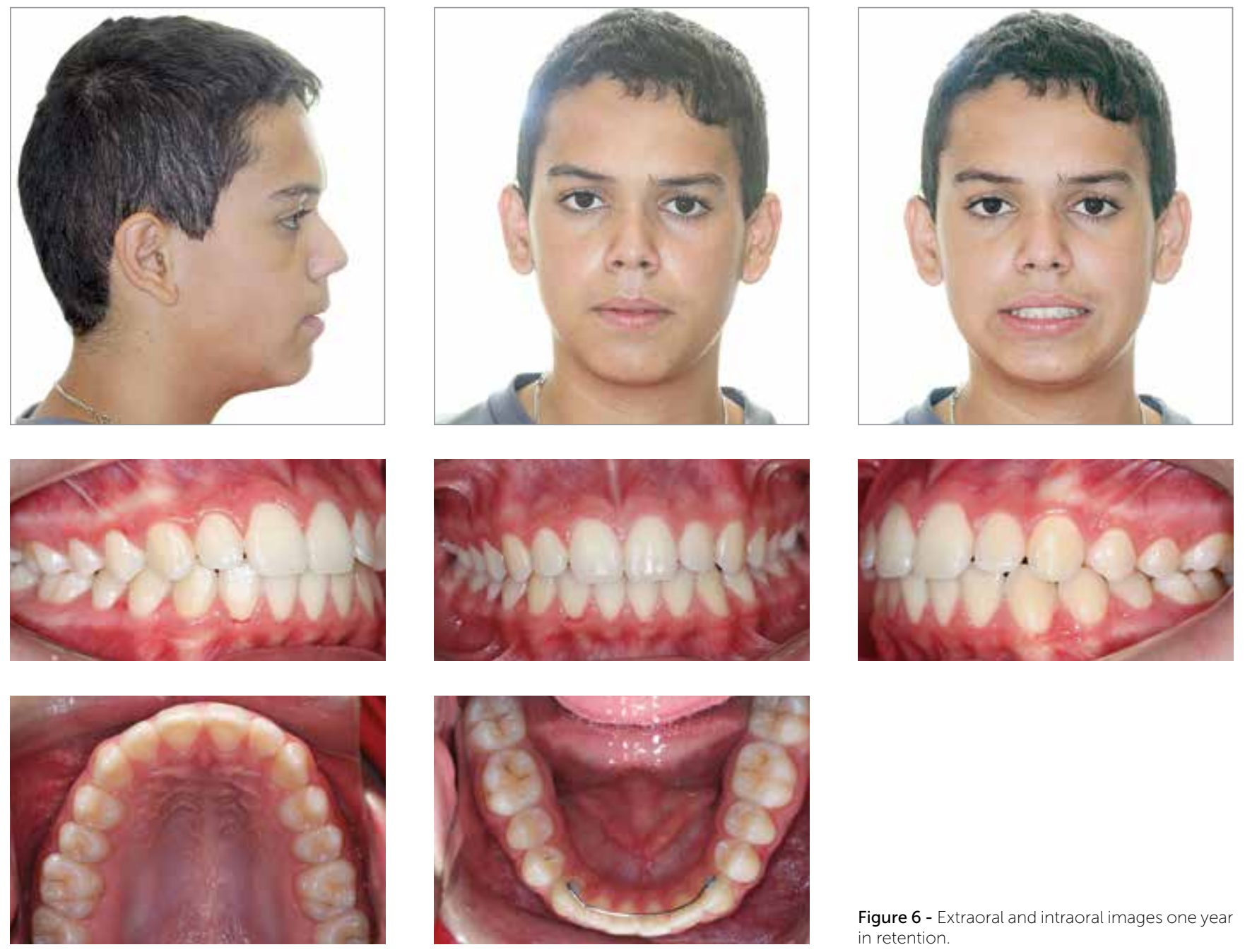

Figure 6 - Extraoral and intraoral images one year in retention.
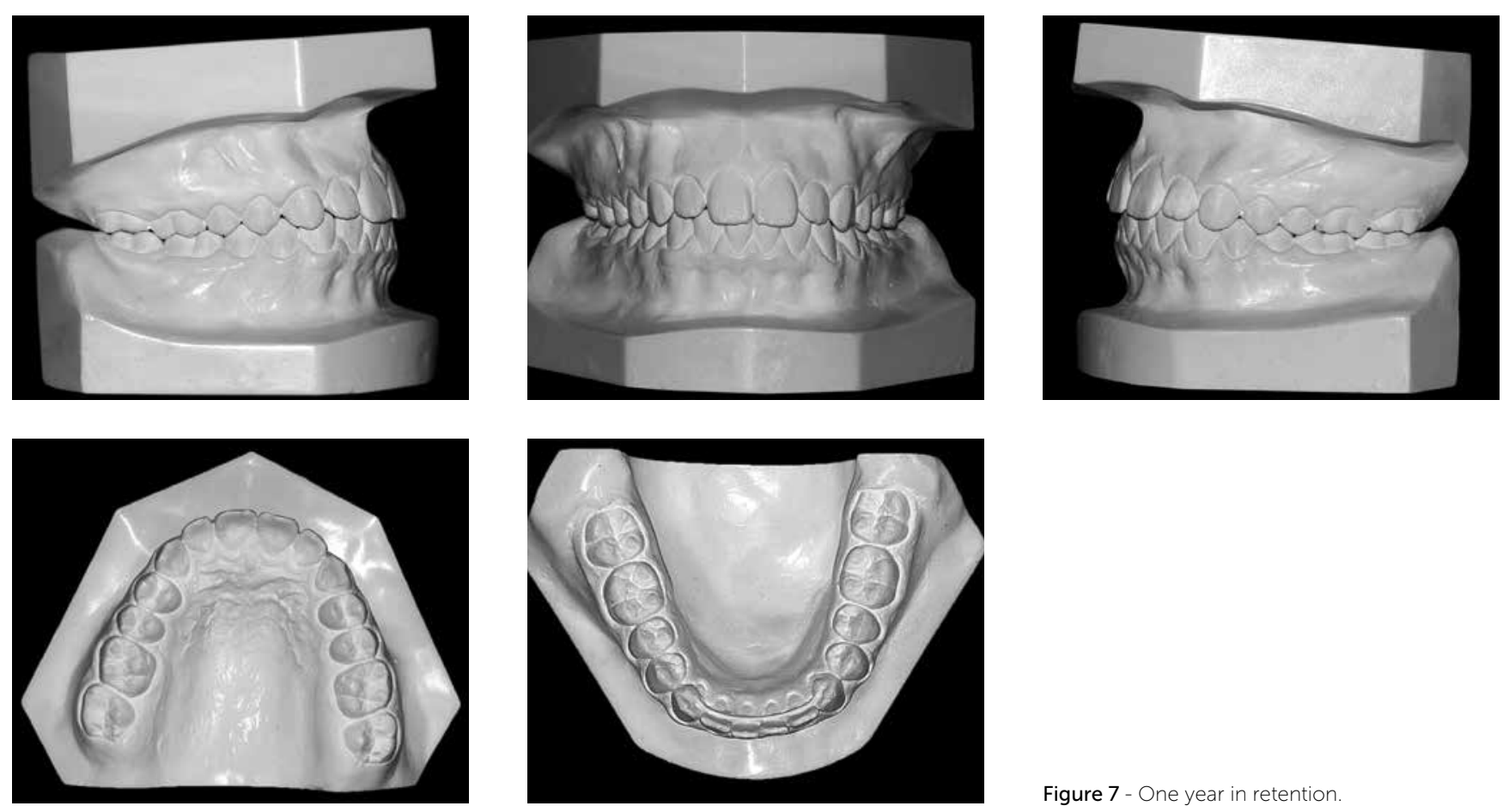

Figure 7 - One year in retention. 
Table 1 - Changes in cephalometric variables during and after treatment.

\begin{tabular}{|c|c|c|c|}
\hline \multicolumn{4}{|c|}{ Skeletal variables } \\
\hline \multicolumn{4}{|l|}{ Maxillary } \\
\hline & Pretreatment & Post-treatment & Retention \\
\hline SNA & 82.2 & 78.9 & 78.9 \\
\hline Co-A & 81.4 & 80 & 80 \\
\hline A-NPerp & 3.3 & 1.5 & 1.6 \\
\hline \multicolumn{4}{|l|}{ Mandibular } \\
\hline & Pretreatment & Post-treatment & Retention \\
\hline SNB & 77.4 & 76.6 & 76.7 \\
\hline Co-Gn & 106.9 & 109.1 & 109.6 \\
\hline P-NPerp & -0.4 & -5.7 & -5.8 \\
\hline \multicolumn{4}{|c|}{ Maxillomandibular } \\
\hline & Pretreatment & Post-treatment & Retention \\
\hline ANB & 4.8 & 2.2 & 2.2 \\
\hline NAP & 8.2 & 2.9 & 2.9 \\
\hline \multicolumn{4}{|l|}{ Growing } \\
\hline & Pretreatment & Post-treatment & Retention \\
\hline SN.GoGn & 38.1 & 39.2 & 39.1 \\
\hline Sn.PP & 7.4 & 6.1 & 6.2 \\
\hline LAFH & 62.9 & 67.9 & 68 \\
\hline \multicolumn{4}{|c|}{ Dentoalveolar variables } \\
\hline \multicolumn{4}{|l|}{ Maxillary } \\
\hline & Pretreatment & Post-treatment & Retention \\
\hline 1.PP & 114.6 & 118.4 & 118.5 \\
\hline 1.NA & 25 & 33.4 & 33.5 \\
\hline $1-N A$ & 5.4 & 8.9 & 9.0 \\
\hline 1-ENAperp & -2.4 & -2.2 & -2.2 \\
\hline 1-PP & 28.6 & 29.7 & 29.8 \\
\hline 6-PP & 20.9 & 22.3 & 22.6 \\
\hline 6-ENAperp & -28.6 & -30.9 & -30.8 \\
\hline \multicolumn{4}{|l|}{ Mandibular } \\
\hline & Pretreatment & Post-treatment & Retention \\
\hline 1.NB & 28.3 & 34.7 & 34.8 \\
\hline $1-N B$ & 5.3 & 8.8 & 8.8 \\
\hline 1-Pogperp & -11.4 & -7.4 & -7.5 \\
\hline 1-GoMe & 38.1 & 39.6 & 39.8 \\
\hline 6-Pogperp & -30.0 & -28.9 & -28.8 \\
\hline 6-GoMe & 26.4 & 29.4 & 29.5 \\
\hline \multicolumn{4}{|c|}{ Dental Relation } \\
\hline & Pretreatment & Post-treatment & Retention \\
\hline Molar relation & -1.4 & 2.5 & 2.5 \\
\hline Overjet & 6.0 & 2.9 & 3.0 \\
\hline Overbite & 5.2 & 0.8 & 1.0 \\
\hline \multicolumn{4}{|l|}{ Soft tissues } \\
\hline & Pretreatment & Post-treatment & Retention \\
\hline NLA & 105.0 & 108.2 & 110.0 \\
\hline UL-E & 0.7 & 2.7 & 2.6 \\
\hline LL-E & -1.6 & -1.8 & -1.6 \\
\hline
\end{tabular}

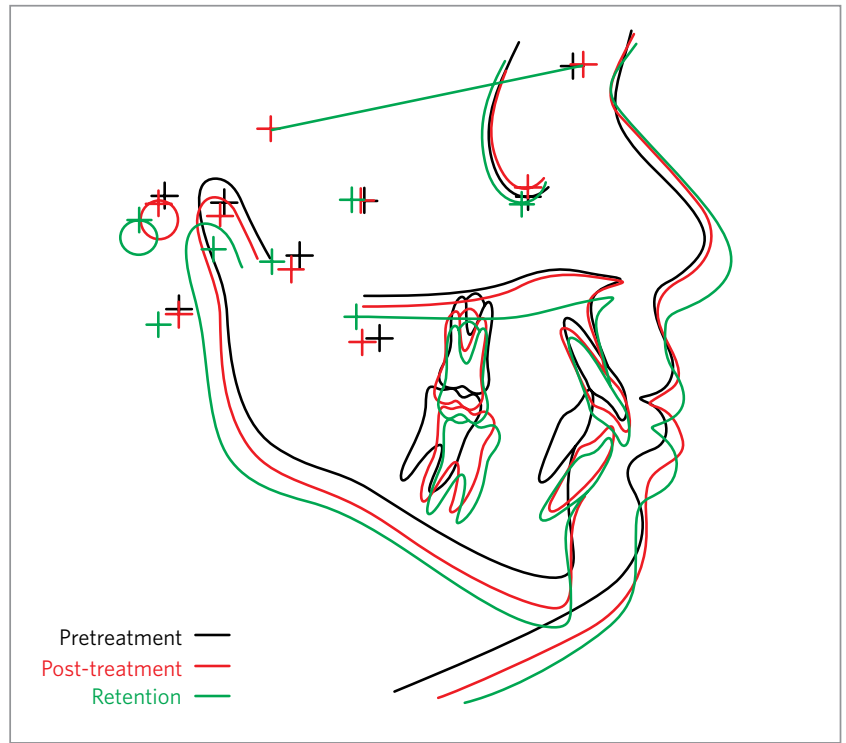

Figure 8 - Cephalometric tracings superimposition: pretreatment (black): post-treatment (red); retention (green).

of the upper dentition. The intrusive force resulted in intrusion of mandibular incisors and upper first molars (1-GoMe and 6-PP) on Table 1. The ANB angle reduced 2.6 degrees. The intrusion of the upper molars and lower incisors caused the functional inclination of the occlusal plane. The lower anterior and total facial height increased from 62.9 to $67.9 \mathrm{~mm}$ when the Jasper Jumper was used and remained constant one year later. The smallest reduction on the anteroposterior mandibular position in relation to the cranial base (SNB), -1.2 degrees during the treatment, can be attributed to the clockwise mandibular rotation, as found in previous studies. ${ }^{4}$ On the other hand, no skeletal effects were found on mandibular growth. Our results agree with the findings of Cope et $\mathrm{al}^{4}{ }^{4}$ Küçükkeles and Orgun, ${ }^{8}$ but it contradicts Weiland et al. ${ }^{13}$ There was a slight mandibular posterior rotation due to extrusion of lower molars (SN.GoGn). In addition to the vertical movement, the lower molars also moved mesially and the upper molars distally, assisting the dentoalveolar Class II correction. The upper incisors uprighted 12.4 degrees in relation to $\mathrm{SN}$, although the lower incisors tended to flare. In this case, the lower incisor angle with line NB increased 6.4 degrees, when added to the upper incisor movement, contributed to most of the reduction of the excessive overjet. The patient was seen one year after treatment and the results were very satisfying (Figs 6, 7 and 8). The overjet and overbite were correct and remained stable one year after the treatment. 


\section{CONCLUSION}

The Jasper Jumper appliance is an alternative treatment for Class II malocclusion in the permanent dentition in non-cooperative patients correcting this malocclusion through more dentoalveolar than skeletal effects. The only skeletal effect is the restricted growth of the maxilla, but with no significant variations on craniofacial growth standard, although a slight posterior rotation of the mandible occurs. Dental changes, as the protrusion of lower incisors and the uprighting of upper incisors are positive for the correction of Class II malocclusion. The dental relation (overjet, overbite and molar relation) is improved with this individualized treatment.
REFERENCES

1. Bishara SE, Ziaja RR. Functional appliances: a review. Am J Orthod Dentofacial Orthop. 1989:95(3):250-8

2. Bowman SJ. One-stage versus two-stage treatment: are two really necessary? Am J Orthod Dentofacial Orthop. 1998;113(1):111-6.

3. Champagne M. The Jasper Jumper technique. 1992;9(2):19-21, 24-5.

4. Cope JB, Buschang PH, Cope DD, Parker J, Blackwood HO. Quantitative evaluation of craniofacial changes with Jasper Jumper therapy. Angle Orthod. 1994;64(2):113-22

5. Ingervall B. Prevalence of dental and occlusal anomalies in Swedish conscripts. Acta Odontol Scand. 1974;32(2):83-92.

6. Jasper JJ. The Jasper Jumper: a fixed functional appliance. Sheboygan, Wisconsin: American Orthodontics; 1987

7. Kim YH. A comparative cephalometric study of Class II, Division 1 nonextraction and extraction cases. Angle Orthod. 1979;49(2):77-84

8. Kuçükkles N, Orgun A. Correction of Class II malocclusions with a Jasper Jumper in growing patients. Eur J Orthod. 1995;17(5):445.

9. McNamara JA Jr. Components of Class II malocclusion in children 8-10 years of age. Angle Orthod. 1981;51(3):177-202

10. Quintão C, Helena I, Brunharo VP, Menezes RC, Almeida MA. Soft tissue facial profile changes following functional appliance therapy. Eur J Orthod. 2006:28(1):35-41

11. Salzmann JA, editor. Practice of Orthodontics. Philadelphia: J. B. Lippincott; 1966

12. Stucki N, Ingerval B. The use of the Jasper Jumper for the correction of Class II malocclusion in the young permanent dentition. Eur J Orthod 1998;20(3):271-81.

13. Weiland FJ, Ingerval B, Bantleon HP, Droacht H. Initial effects of treatment of Class II malocclusion with the Herren activator, activatorheadgear combination, and Jasper Jumper. Am J Orthod Dentofacial Orthop. 1997:12(1):19-27.

14. Woodside DG. Do functional appliances have an orthopedic effect? Am J Orthod Dentofacial Orthop. 1998;113(1):11-4 